\title{
Disposition towards Participation in Dance as a Recreational Activity among Undergraduates in University of Ilorin, Nigeria
}

\author{
BAKInde, S, T, Ph.D ${ }^{1 *}$, Olaitan, O, L Ph.D ${ }^{2}$, ADEBAyO, B.S. Ph.D ${ }^{3}$, AJADI, M.T, Ph.D ${ }^{4}$ \\ ${ }^{1,3,4}$ Department of Human Kinetics Education, University of Ilorin, Ilorin, Nigeria \\ ${ }^{2}$ Department of Health Promotion and Environmental Health Education, University of Ilorin, Ilorin, Nigeria \\ *Corresponding Author: BAKINDE, S, T, Ph.D, Department of Human Kinetics Education, University \\ of Ilorin, Ilorin, Nigeria
}

\begin{abstract}
People dance to express their feelings on different occasions, either for joy, sadness or for entertainment. It has been established in literature that dance is an avenue for physical exertion specialized kinds of movement are required for appropriate execution of dance steps. This study examined the attitude towards dance as a Recreational activity among undergraduates of university of Ilorin. Six (6) hypotheses were formulated for this study. Descriptive research design was used for the study; data was collected using structured questionnaire and analyzed using descriptive and inferential statistics of percentage and ChiSquare $\left(X^{2}\right)$ respectively. All hypotheses were tested at 0.05 alpha level. The result revealed that significant difference exists in dance participation of both male and female students in university of Ilorin. The results also revealed that significant difference exists in dance participation of both Christian and Muslim. The study recommended that dance as an activity should be designed in such a way that it will attract students' interest.
\end{abstract}

Keywords: Disposition. Participation. Dance, Recreational activity, Undergraduates

\section{INTRODUCTION}

Dance is an event where people express their feelings about people, events and surroundings, characterized by movements which are directly proportional to the rhythm of sound and/or music. Dance is a form of recreation that provides emotional enjoyment. Babalola and Fadoju (2001) say dance is the attempt to perform the life of early sculpture, painting and poetry by movement. Dance is a competitive sport, because it is contested and because it's made for fun, it is also an art. Dance is a sport that is competitive and guided by rules; it can be challenged in a large group or individually. Dance is also a form of recreation, as it can be performed for fun during leisure hours. Dance could be described as the body's continuous move at a certain rhythm and in a particular area. It could be an expression of emotion, an excessive energy outlet or a source of happiness.

Wehmeir (2000) defined dance as a series of motion and steps in time with music, usually with a partner, alone or in a group, in rhythmical steps. Dance is an important part of basic to tertiary physical education programs. Some authors regard dance as a social and ethnic activity that complements and expands their understanding of this activity as a cultural phenomenon. Dance shares the same media as games, sports and swimming and requires similar practical mastery of the body. But the dance differs from them because it is not used as a practical movement but as the artistic vehicle of expression. Through dance, participants develop positive personality, emotional well-being and have an inner feeling of happiness, self-confidence. It was also observed that body flexibility, strength and cardiovascular resistance can be improved. Recreation refers to physical activity that an individual undertakes during the hours of leisure after work (Oduyale \& Amuchie 2002). The authors also explained that recreation and sports are both synonymful but different; the most important characteristics of recreation are: voluntary, pleasurable to the participant, voluntary, voluntary, nonstoppable skill or rigorous training and competitive in nature. It has to be a synonym for recreation and sports. On the other hand, sport always has a competitive nature, rules and regulations are binding on participants, rigorous training takes place, and normally there are rules to begin, end and determine the winner. Participation in recreational activities offers a refreshing body and mind, efficient use of recreational hours, the opportunity to make new friends and to socialize with the elderly, and a 
relaxed and unnecessary atmosphere. Oduyale \& Amuchie (2002) affirmed that the choices of recreational activities have been determined by various factors, including participation, employment, skills, age, sex, educational backgrounds and the facilities to be used. According to Greendor (2002), students are encouraging and enhancing their attitudes to the sporting of games and recreational activities from many sources. Kenyo and Mopherson (2002) further observed that students were primarily influenced by their parents and the available school facilities that motivate each student to participate in leisure activities. Olusoji (2008) pointed out that recreational activities are one of the basic conditions needed to maintain a high standard of living when performed optimally. We all know that when one recreates regularly, total physical fitness is developed. Ajala, Amusa and Sohi (2008) reaffirmed that health-related recreation is important in order to maintain the body's vitality. Many people know that regular recreation activities would be beneficial, but because of the misconceptions on recreation programmes, they remain sedimentary and physically inactive. If one does, it can lead to weakness of the general body.

According to Juny (2007), the attitudes of extroversion and introversion are two major personality attitudes. The extroverted attitudes orient a person towards an external objective world, while the introverted attitudes orient the person towards an inner subjective world, one of which is usually dominated and conscious for various people, whereas the other is subordinate. Maccoby (2008) argued that gender role socialization, such as sex and stereotyping, is theoretically based on social learning and role model imitation. Social education underlines parental rewards for sex-specific behaviour, this clearly means different treatment according to a child's sex, and differential expectations and differences in personality determines one's participation in various types of physical skill activities. Such a difference is usually attributed to certain antecedent factors relating to sex stereotyping and sex-based socialization expectations, especially in the family at the initial stage. The keyword is the interest that needs to be defined based on the above explanations. By definition, a Latin word "it's between" means something interesting to someone to help him recognize a connection. An object that is not interesting itself can be created, so that it implies that it has certain values that help to satisfy some need by being associated with an object. Thus it is important to meet or to create a need for students to be interested in any activity and to sustain it.

\section{Statement Of The Problem}

Students participate in dance only when they are at social meetings such as birthdays, picnics, burning - fires, dinners, parties, etc. Many students in Ilorin University have been noted that they do not recognize the importance of recreation. Many of them think dance is intended for people who don't value time. They still have to understand the health, social and educational benefits of dance. Therefore, this research is aimed at examining the willingness of Ilorin university students to dance as a leisure activity.

\subsection{Purpose of the Study}

The purpose of this study was to:

- Find out if gender has influence on student's disposition towards participation in dance as a recreational activity among University of Ilorin students

- Assess whether religious belief has influence on participation in dance as a recreational activity among University of Ilorin students

- Examine the role of family background towards participation in dance as recreational activity among University of Ilorin students

- Determine the role of educational background on participation in dance as a recreational activity.

- Find out the influence of socio-economic status on the disposition towards participation in dance among University of Ilorin students.

\subsection{Hypotheses}

The following hypotheses were tested at 0.05 level of significant

- There is no significant influence of ge nder on the disposition of students of university of Ilorin towards dance participation. 
Disposition towards Participation in Dance as a Recreational Activity among Undergraduates in University of Ilorin, Nigeria

- There is no significant influence of religious b e l i e f on the disposition of students of university of Ilorin towards dance participation.

- There is no significant influence of family background on students' disposition towards dance as a recreational activity in University of Ilorin.

- There is no significant influence of educational background on the disposition of students of university of Ilorin towards dance participation.

- There is no significant influence of socio - economic status on disposition towards participating in dance.

\section{METhOdS AND PROCEDURES}

Descriptive research of the survey type was the research design for this study. University of Ilorin has a population of 21,500 students, with a target population of 9,652 of the six faculties selected. Six of the 15 existing faculties were selected by a simple random technique. The systemic sampling technique was used to select 50 interviewees from the six selected faculties, each of which involved 300 interviewees. To collect data for the study, a validated structured questionnaire was used. The reliability co-efficient " $r$ " of 0.082 was obtained by a test-retest method using the moment correlation of Pearson Product. Descriptive frequency count and percentage statistics were used to analyze demographic data, and Chi-Square (X2) inferential statistics were employed to test the hypotheses at 0.05 level of significance.

\subsection{Results}

Table 1: Demographic information of respondents

\begin{tabular}{|l|l|l|l|}
\hline S/No & Demographic variables & Frequency & Percentage (\%) \\
\hline 1. & Sex & & \\
& Male & 97 & $32.33 \%$ \\
& Female & 203 & $67.67 \%$ \\
& Total & 300 & $100 \%$ \\
\hline 2. & Status & & \\
& Single & 279 & $93 \%$ \\
& Married & 21 & $7 \%$ \\
& Total & 300 & $100 \%$ \\
\hline 3. & Religion & & \\
& Christianity & 117 & 39 \\
& Islam & 183 & 61 \\
& Total & 300 & $100 \%$ \\
\hline 4. & Age & & \\
& $15-20$ & 197 & $65.67 \%$ \\
& $21-25$ & 73 & $24.33 \%$ \\
& $26-30$ & 19 & $6.33 \%$ \\
& 31 years and above & 11 & $3.67 \%$ \\
& Total & 300 & $100 \%$ \\
\hline
\end{tabular}

Table 1 shows that majority of the respondents were female (203) which represents $67.67 \%$ while 97 were male $(32.33 \%)$. Also 279 respondents were single which represents $93 \%$ while 21 respondents (7\%) were married. The table also revealed that 183 which represent $61 \%$ are Islam while 117 respondents which represent 39\% are Christian. The table indicates that 197 respondents are between the ages of 15-20 years which represents $65.67 \%, 73$ respondents were between the ages of 2125 years which represents $24.33 \%, 19$ respondents were between the ages of 26-30 which represents $6.33 \%$ and 11 respondents were above 31years old $3.67 \%$.

Hypothesis 1: There is no significant gender difference in the disposition towards participation in dance among university of Ilorin students. 
Disposition towards Participation in Dance as a Recreational Activity among Undergraduates in University of Ilorin, Nigeria

Table 2: Chi-Square $\left(X^{2}\right)$ analysis on gender difference in disposition towards participation in dance among university of Ilorin students.

\begin{tabular}{|c|c|c|c|c|c|c|c|c|c|c|}
\hline $\mathrm{S} / \mathrm{N}$ & Item & $\mathrm{SA}$ & A & D & SD & RT & Cal. Value & df. & $\begin{array}{l}\text { Crit. } \\
\text { Value }\end{array}$ & Decision \\
\hline & Gender & & & & & & & & & \\
\hline 1. & $\begin{array}{l}\text { It is ideal for male and female } \\
\text { students to dance together }\end{array}$ & 63 & 162 & 48 & 27 & 300 & & & & \\
\hline 2. & $\begin{array}{l}\text { Dance is a form of recreation for } \\
\text { both male and female }\end{array}$ & 165 & 112 & 23 & - & 300 & 159.52 & 6 & 12.59 & Rejected \\
\hline 3. & $\begin{array}{l}\text { Gender determines the attitude } \\
\text { of students towards dance as a } \\
\text { means of recreational activity }\end{array}$ & 184 & 107 & 9 & - & 300 & & & & \\
\hline C.T & & 412 & 381 & 80 & 27 & 900 & & & & \\
\hline
\end{tabular}

Table 2 shows that the Chi-Square calculated value is greater than the critical value i.e. $159.52>$ 12.59 at 0.05 alpha level, the hypothesis is rejected.

Hypothesis 2: There is no significant influence of religious belief on disposition towards dance among university of Ilorin students.

Table 3: Chi-Square $\left(X^{2}\right)$ table on influence of religious belief on disposition towards dance participation among university of Ilorin students.

\begin{tabular}{|l|l|l|l|l|l|l|l|l|l|l|}
\hline S/N & Item & SA & A & D & SD & RT & $\begin{array}{l}\text { Cal. } \\
\text { Value }\end{array}$ & df. & $\begin{array}{l}\text { Crit. } \\
\text { Value }\end{array}$ & Decision \\
\hline & Religion & & & & & & & & & \\
\hline 1. & My religion allows me to dance & 182 & 91 & 16 & 11 & 300 & & & & \\
\hline 2. & $\begin{array}{l}\text { One's religion determines the } \\
\text { recreational activity }\end{array}$ & 82 & 177 & 32 & 9 & 300 & 238.78 & 6 & 12.59 & Rejected \\
\hline 3. & $\begin{array}{l}\text { Participating in dance will } \\
\text { improvemy spiritual level }\end{array}$ & 52 & 104 & 87 & 56 & 300 & & & & \\
\hline C.T & & 317 & 372 & 135 & 76 & 900 & & & & \\
\hline
\end{tabular}

From table 3, the calculated value is greater than the table value $238.78>12.59$ at 0.05 alpha levels. In this case, the hypothesis which states that religious belief of university of Ilorin students does not significantly influence their participation in dance is rejected.

Hypothesis 3: There is no significant influence of family background on disposition towards dance among university of Ilorin students.

Table 4: Chi-Square $\left(X^{2}\right)$ table showing the significant influence of family background on disposition towards dance among university of Ilorin students.

\begin{tabular}{|l|l|l|l|l|l|l|l|l|l|l|}
\hline S/N & Item & SA & A & D & SD & RT & $\begin{array}{l}\text { Cal. } \\
\text { Value }\end{array}$ & df. & $\begin{array}{l}\text { Table } \\
\text { Value }\end{array}$ & Decision \\
\hline & $\begin{array}{l}\text { Family } \\
\text { Background }\end{array}$ & & & & & & & & & \\
\hline 1. & $\begin{array}{l}\text { Parents should support their children } \\
\text { in dance participation }\end{array}$ & 32 & 62 & 119 & 87 & 300 & & & & \\
\hline 2. & $\begin{array}{l}\text { Parents should encourage their } \\
\text { children to participate in dance as a } \\
\text { means of recreational activity }\end{array}$ & 21 & 48 & 139 & 92 & 300 & 12.16 & 6 & 12.59 & Accepted \\
\hline 3. & $\begin{array}{l}\text { My siblings introduce me to } \\
\text { participate in dancing activity }\end{array}$ & 21 & 44 & 147 & 88 & 300 & & & & \\
\hline C.T & & 74 & 154 & 405 & 267 & 900 & & & & \\
\hline
\end{tabular}

The information from table 4 indicates that calculated value is less than the table value $12.16<12.59$ at 0.05 alpha levels; by implication the hypothesis is accepted.

Hypothesis 4: There is no significant influence of educational background on disposition towards dance among University of Ilorin students.

Table 6: Chi-Square $\left(X^{2}\right)$ table showing influence of educational background of on dance participation among University of Ilorin students

\begin{tabular}{|l|l|l|l|l|l|l|l|l|l|l|}
\hline S/N & Item & SA & A & D & SD & RT & $\begin{array}{l}\text { Cal. } \\
\text { Value }\end{array}$ & df. & $\begin{array}{l}\text { Crit. } \\
\text { Value }\end{array}$ & Decision \\
\hline & $\begin{array}{l}\text { Educational } \\
\text { Background }\end{array}$ & & & & & & & & & \\
\hline 1. & $\begin{array}{l}\text { Participating in dance may improve } \\
\text { my educational performance }\end{array}$ & 89 & 92 & 73 & 46 & 300 & 212.06 & 3 & 7.81 & Rejected \\
\hline 2. & $\begin{array}{l}\text { I engage in dancing activities } \\
\text { because of the educational vahues }\end{array}$ & - & 16 & 197 & 87 & 300 & & & & \\
\hline C.T & & 89 & 108 & 270 & 133 & 600 & & & & \\
\hline
\end{tabular}

International Journal of Sports and Physical Education (IJSPE) 
Disposition towards Participation in Dance as a Recreational Activity among Undergraduates in University of Ilorin, Nigeria

Table 5 reveals that the calculated value is greater than the critical value $212.06>7.81$ of degree of freedom at 0.05 alpha level. The null hypothesis that the educational background does not significantly influence participation in dance among University of Ilorin students is rejected.

Hypothesis 5: There is no significant influence of socio-economic status on disposition towards dance among University of Ilorin students.

Table 6: Chi-Square $\left(X^{2}\right)$ table on influence of socio-economic status on disposition towards dance participation among University of Ilorin students.

\begin{tabular}{|c|c|c|c|c|c|c|c|c|c|c|}
\hline $\mathrm{S} / \mathrm{N}$ & Item & SA & $\bar{A}$ & $\mathrm{D}$ & SD & RT & $\begin{array}{l}\text { Cal. } \\
\text { Value }\end{array}$ & df. & $\begin{array}{l}\text { Table } \\
\text { Value }\end{array}$ & Decision \\
\hline & $\begin{array}{l}\text { Socio-Economic } \\
\text { Factor }\end{array}$ & & & & & & & & & \\
\hline 1 . & $\begin{array}{l}\text { Social interaction determines the } \\
\text { level of dance participation }\end{array}$ & 146 & 123 & 31 & & 300 & & & & \\
\hline 2. & $\begin{array}{l}\text { The economic status of our country } \\
\text { has driven people away from } \\
\text { dancing activity as a means of } \\
\text { recreation }\end{array}$ & 182 & 118 & - & & 300 & 77.85 & 6 & 12.59 & Rejected \\
\hline 3. & $\begin{array}{l}\text { The government or private } \\
\text { institution has not given better } \\
\text { financial support for recreational } \\
\text { activity }\end{array}$ & 208 & 92 & - & - & 300 & & & & \\
\hline C.T & & 536 & 333 & 31 & & 900 & & & & \\
\hline
\end{tabular}

Table 6 indicates that the calculated value is greater than the table value $77.85>12.59$ with degree of freedom at 0.05 alpha level. Therefore, the null hypothesis says that there is no significant influence in the socio-economic an individual towards participation in dance as a means of recreational activity among University of Ilorin students is rejected.

\section{DISCUSSION OF FINDINGS}

The findings showed that students of the University of Ilorin have a positive disposition to dance as a recreational activity. It has been revealed that the role of gender in dance participation especially among students of Ilorin University cannot be overlooked, where both sexes take part actively in recreational activities, as Olusanyin (2008) stated. The results show that faith influences dance participation whether it is Islam or Christianity. Each religion considers it as a recreational activity, especially among students of the University of Ilorin, and this finding supports that of Bourguignon (2004) and Fisher (2008), and affirms that religious doctrines encourage participation in physical work to enhance physical well-being. It also showed that educational backgrounds play a major role in dance participation as a form of leisure activities among University of Ilorin students. Pesic (2002) affirmed that people tend to participate more when they understand the benefits of dance. The socio-economic factor in dance participation also influenced dance participation as a means of recreation. The socio-economic status of Harper (2011) plays a key role in determining the patterns of involvement in physical activities. Those with a high socio-economic level are more likely than the middle- and low-class physical activities due to their expertise and exposure.

\section{CONCLUSION AND RECOMMENDATIONS}

From the above, dance can be affirmed as the most natural human activity. Dance is good work for development, strength, endurance, power, flexibility and good coordination of the body. Students could gain ample opportunity if dance could be integrated into the university's recreation programmes. The results of this study showed that there was no significant gender difference in the participation in dance. It was also observed that an individual's level of education does not affect their involvement in dance. The participants also agreed that Christians and Muslims participate without any compulsion in dancing activities. This study also revealed that dancing activities offer different opportunities for all ages to enjoy satisfying experiences related to their needs.

Based on the findings, it was recommended that:

- University of Ilorin management should encourage and integrate dance into recreational and leisure programmes of the school so that the students can realize their potentials.

- School authority should find a means to involve private organizations to assist the university by donating recreational equipment and facilities. 
Disposition towards Participation in Dance as a Recreational Activity among Undergraduates in University of Ilorin, Nigeria

- Workshops, seminars and conferences should be organized to enlighten both male and female students on the benefits they can derive from dancing activities

- Dance education should be introduced as a course to be offered by students in the university to be taught under the General Studies (GNS) courses.

- It is important that dance should be incorporated into the recreational programme of the university especially due to the low level of stress involved and the fact that the risk of injury is minimal compared to other activities.

\section{REFERENCES}

[1] Amusa, L.O. (2005) Community Recreation and Agency. Ibadan: Heinemann Publisher

[2] Arnold, S.E. (2008) Recreation and Competitive Sports. Journal of National Association of Physical Health and Recreation. Ibadan: University Press

[3] Babalola ,J.F.\&Fadoju,A.O.(2001). The psycho-physiological relevance of dance in the training of physical educators. In Awosika Y.I.,BabalolaJ.F., Fabunmi M.,Osiki,J.O. and Emunemu, B.O.(Eds.) topical issues in Education: papers in honour of Prof.C.O..Udoh.fac.of Education University of Ibadan.

[4] Bramel, S. (2006) Introduction to Community Recreation. New York: Mcgraw Hill Company

[5] Bucher, C.A. (2005) Importance of Recreation. New York Mc Graw Hill Company

[6] Cattel, S.A. (2008) Brief History of Parks in West African. Lagos: Longman

[7] Cogan, L.O. (2007) Fundamental of Physical Education, Saint Louis: C.V. Mosby Company

[8] Enekwe, O.A. (2002) Recreation and Democracy Development. Lagos: Longman Farlex dictionary 2005 edition

[9] Jung, L.O. (2007). Dance, The Living Culture of Nigeria: Lagos Herncemen Publisher

[10] Kanyon and Mopherson (2008) Dance as a Cultural Expression. New York. Lynn Limited

[11] Laban, S. (2005) Physical Education and Sport Philosophy New Jersey Prentile hill

[12] Logan and Paxson (2008) the History of Dance in London: Orbis Publishing Limited.

[13] Management, Y. (2009) Dance as a Cultural Expression. New York: McGraw hill

[14] Meki, J.A (2002) Dance Composition Cambridge: University Press

[15] Merriam Webstar Dictionary 2005 Edition

[16] Michael, J.C. (2007) Recreation and Dance. Ibadan: Evans Publisher

[17] Nwankwo, E.L. (2005) Physical Education and Recreation. Ibadan University Press

[18] Ogunbiyi, O.T. (2005) Physical Education and Recreation: Ibadan University Press

[19] Olusanyi, O. (2007) the Function of Dance in Human Society. Ibadan: University Press

[20] Oyeleye, O.A. (2004) the True Meaning of African Dance. Lagos, Evans Publisher

[21] Saint, E.J (2006) Recreational Development, Florida: Prentice Hall Company

Citation: BAKINDE, S, T, Ph.D, et.al. "Disposition towards Participation in Dance as a Recreational Activity among Undergraduates in University of Ilorin, Nigeria" International Journal of Sports and Physical Education (IJSPE), vol 6, no. 4, 2020, pp. 07-12. doi: https://doi.org/10.20431/2454-6380.0604002.

Copyright: () 2020 Authors. This is an open-access article distributed under the terms of the Creative Commons Attribution License, which permits unrestricted use, distribution, and reproduction in any medium, provided the original author and source are credited. 